Melanie Groß* and David Kertai

\title{
Becoming Empire: Neo-Assyrian palaces and the creation of courtly culture
}

https://doi.org/10.1515/jah-2018-0026

\begin{abstract}
Assyria (911-612 BCE) can be described as the founder of the imperial model of kingship in the ancient Near East. The Assyrian court itself, however, remains poorly understood. Scholarship has treated the court as a disembodied, textual entity, separated from the physical spaces it occupied - namely, the palaces. At the same time, architectural analyses have examined the physical structures of the Assyrian palaces, without consideration for how these structures were connected to people's lives and works. The palaces are often described as secluded, inaccessible locations. This study presents the first model of the Assyrian court contextualized in its actual palaces. It provides a nuanced model highlighting how the court organized the immense flow of information, people and goods entering the palace as a result of the empire's increased size and complexity. It argues that access to the king was regulated by three gates of control which were manned by specific types of personnel and a more situational organization that moved within the physical spaces of the palace and was contingent on the king's activity.
\end{abstract}

Keywords: court culture, kingship, Assyrian Empire, royal palace

As the first in a long sequence of empires to rule the Middle East, Assyria can be described as the founder of the imperial model of kingship. Its experiments in becoming an empire and the resulting courtly culture informed the empires that

Anmerkung: This joined study has been supported by the Martin Buber Society of Fellows in the Humanities and Social Sciences at the Hebrew University of Jerusalem. Melanie Groß conducted the study in the framework of IAP VII "Greater Mesopotamia" and the ERC-CoG-2015 - ERC Consolidator Grant Project “Persia and Babylonia” (ID 682241). Abbreviations are according to PNA 3/II, B31-B36.

\footnotetext{
*Corresponding author: Melanie Groß, Leiden University, Matthias de Vrieshof 4, 2311 BZ Leiden, The Netherlands, E-Mail: m.m.gross@hum.leidenuniv.nl

David Kertai, Martin Buber Society of Fellows in the Humanities and Social Sciences at the Hebrew University of Jerusalem, Mandel Building 352, 91905 Jerusalem, Israel, E-Mail: dkertai@yahoo.com
} 
came in its wake. Notwithstanding these successes, the Assyrian kings have a ruthless image in the historical recollection, one that they sought to propagate about themselves, and that has since been reiterated in the Biblical and Classical sources, as well as in scholarship. This scholarship, centered as it has been on political and military history, often stressed the idea of Assyrian king as an omnipotent despot ruling at his own whim. More recently research on Assyria has focused on royal ideology and its manipulation through art and texts. ${ }^{1}$ Scholarship has enriched this view by exploring the inner workings of the Assyrian state and its functionaries, as well as the internal communication within that state. ${ }^{2}$ While significant, this scholarship has treated the court as a disembodied, textual entity, separated from the physical spaces it occupied - namely, the palaces. At the same time, architectural analyses have examined the physical structures of the Assyrian palaces, without consideration for how these structures were connected to people's lives and works. This paper examines the Assyrian court as it functioned within its physical space. It argues that the spatial arrangement of the palace was closely tied to courtly life. Combining spatial and textual evidence, we suggest that space was crucial to the formation of one of the earliest courtly cultures in the world, and that the spatial organization of the royal palaces was determined by how the household of the Assyrian king was structured and organized.

The Neo-Assyrian Empire originated as a city state, centered on the city of Assur and its eponymous god, in the first half of the second millennium BCE (Fig. 1). ${ }^{3}$ After it gained independence from the Mitanni Kingdom in the middle of the fourteenth century, Assyria's (mis)fortunes were guided by a single dynasty. Lasting until the empire's demise in c. 612, the royal house became one of the longest lasting reigning dynasties in history. Located in a region delineated by the cities Assur, Nineveh (modern Mosul) and Arbela (modern Erbil) in the north of modern-day Iraq, ${ }^{4}$ Assyria grew into what could be described as one of the first empires under the rule of Tiglath-pileser III (744-727), at which point Assyria came to rule an extensive heterogeneous territory. His successors continued to expand the empire, which at different times encompassed Egypt in the west and Elam in the east during the reigns of kings Esarhaddon (680-669) and Assurbanipal (668-627).

1 For instance, Winter (1983); Porter (1993); Pongratz-Leisten (2015); Karlsson (2016).

2 For instance, Mattila (2000); Groß (2014); Radner (2014); Svärd (2015); Richardson (2016).

3 Liverani (2011).

4 Radner (2011a). 


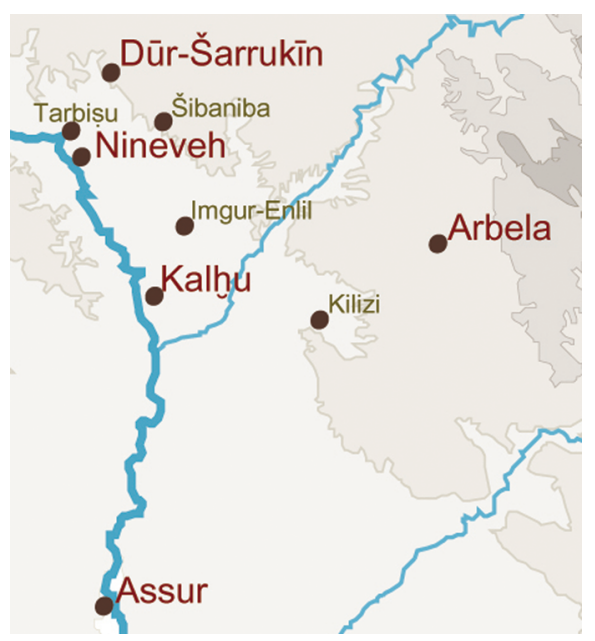

Figure 1: Map of central area of Assyria (by D. Kertai)

Assyria can be described as the founder of the imperial model of kingship in the ancient Near East. ${ }^{5}$ The Assyrian court itself, however, remains poorly understood. Its palaces are often described as secluded, inaccessible locations, leading to the simplistic suggestion that they were divided into public and private areas. This study will present a more nuanced model highlighting how the court organized the immense flow of information, people and goods entering the palace as a result of the empire's increased size and complexity. It argues that access to the king was controlled not by a strict division into public and private spaces, but rather by three gates of control which were manned by specific types of personnel and a more situational organization that moved within the physical spaces of the palace and was contingent on the king's activity. This reconstruction presents the first spatial model of the Assyrian court contextualized in its actual palaces. Understanding how this early imperial court functioned provides insight into the creation of other ancient courtly cultures, for which Assyria was the precursor.

5 See, for instance, Lavan, Payne and Weisweiler (2016); Bang and Kołodziejczyk (2017); Liverani (2017). 


\section{The sources}

The available sources for reconstructing Assyrian courtly culture are the physical remains of Assyria's palaces, as well as artistic depictions and textual evidence about the workings of those palaces. The presence of multiple urban centers and the establishing of new royal centers - Kalhu under Aššurnașirpal II (883-859), ${ }^{6}$ Dūr-Šarrukīn under Sargon II (722-705) ${ }^{7}$ and Nineveh under Sennacherib (704$681)^{8}$ - resulted in an extensive and diverse corpus of palaces that is exceptional within the history of the ancient Middle East (Fig. 2). Each capital contained at least a primary and a military royal palace. ${ }^{9}$ The most extensive information comes from the two main palaces of Kalhu, which were constructed in the ninth century. ${ }^{10}$ They were occupied by the royal court until the end of the reign of Sargon II, ${ }^{11}$ but remained in use until the end of the Assyrian Empire. Dūr-Šarrukin was abandoned almost immediately after its inauguration. Nineveh formed the primary royal city throughout the seventh century. Despite more than 150 years of excavations, our knowledge is still rather fragmentary. Earlier excavations mostly concentrated on the monumental areas of the palaces. Inventory from the palaces of Dūr-Šarrukīn and Nineveh is almost entirely unknown except for some special find categories such as texts.

6 Mallowan (1966); Kertai (2015), 17-82.

7 The main palace of Dūr-Šarrukīn was completely excavated by Paul-Émile Botta (Botta 1849) and Victor Place (Place 1867), but its floorplan is tentative at best, see Kertai (2015), 87-92. Only the more monumental parts of the city's military palace are known, see Loud and Altman (1938), 7578; Kertai (2015), 117-120.

8 The inner and outer areas of Sennacherib's royal palace in Nineveh are almost entirely unknown. The same is true for the later North Palace of Assurbanipal. The military palace, which stood on Nebi Yunus, is almost entirely unknown.

9 Kertai (2013) and (2015).

10 Except for the possible forecourts of the Northwest Palace, both palaces have been excavated almost completely. The forecourts of Fort Shalmaneser are somewhat atypical as the complex incorporated military functions. This explains the presence of workshops for the repair of chariots (Oates and Oates 2001, 156). Most rooms surrounding these courts formed storage spaces where booty was stored.

11 Kertai (2013), 11-18. 


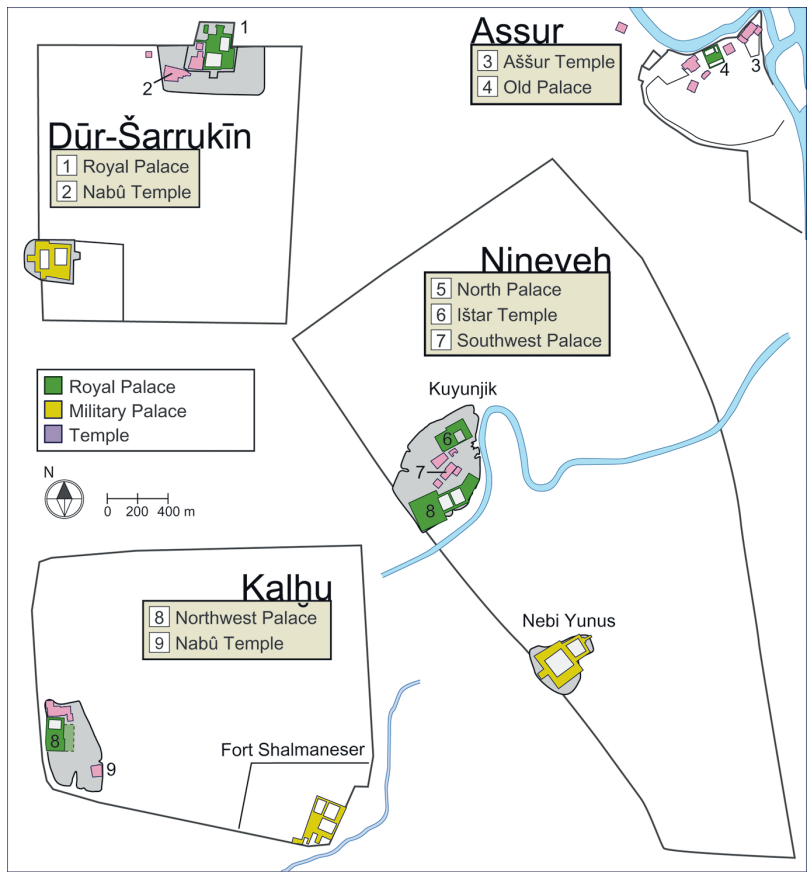

Figure 2: Plans of the main Assyrian royal cities (by D. Kertai).

Most spaces within the palace were either storage, bathroom or reception rooms. ${ }^{12}$ Reception rooms had a variety of possible purposes, making it difficult to pin down their exact use in each case. The architecture of most rooms is generic and includes almost no recognizable installations. This, however, reflects the fact that most spaces were flexible, used for different needs at different times. Information on the more specific uses of rooms is minimal. Palaces were divided into suites, with the most basic suite containing a reception room and a bathroom. Suites may have been used for residential purposes, but there was no clear distinction between residential and non-residential architecture. It appears that suites were built with a focus on their daytime purpose, namely receiving guests. ${ }^{13}$ They might be described as offices, in the sense of having been occupied by a specific official. Most high officials possessed houses outside the palace, using their suites primarily for work, although they could also be used for residential purposes. The elaborate suites that were located close to the monumental core of

12 Kertai (2015), 185-204.

13 Kertai (2015), 225-229. 
the palace, for instance the suites surrounding the royal courtyard in the Northwest Palace of Kalhu, were more likely to be residential, but will also have functioned as the offices and reception suites of the people living in these parts of the palace such as the queen and the royal offspring (as long as they had not moved out into their own residences).

In addition to the palace architecture, Assyrian art also provides a few glimpses into the functioning of the court. The stone slabs covering the walls of the more important rooms provide evidence of specific court activities. They depict mainly military scenes, but also include a few royal hunts, religious ceremonies and banquets. Other significant depictions, which are comparatively rare, can be found on decorated metal slabs of wooden gates, ivory plaques and seals.

While the visual and architectural sources are spread out over time, the textual sources in the Akkadian language - mostly written in the cuneiform script on clay tablets - are much more concentrated. Textual information about earlier periods is limited and mainly consists of royal inscriptions which usually do not provide information about the inner workings of the royal court. Cuneiform sources providing information on the palace household for the most part date to the second half of the eighth century and to the seventh century and were found predominantly in the palaces of Kalhu and Nineveh. The bulk of texts at our disposal are letters, administrative documents and legal records associated with different court officials. While the Kalhu material allows a more hands-on insight into the daily palace businesses, it partly reflects the palaces' use after the court had moved away.

The picture of the palace household that can be created on the basis of the written sources remains fragmentary. Not only are they unevenly distributed over time and space, but they are also difficult to interpret. This is particularly due to the fact that most texts are not concerned with the internal processes of the palace household, but relate to provincial administration, military actions and other state affairs. This problem is compounded by the use of perishable writing materials such as papyrus, leather, and wax tablets made of wood or ivory. These were used for cuneiform texts, but especially for Aramaic documentation. Along with the growing population share of Aramaic speaking people who migrated and were deported from the west, Aramaic developed into the new lingua franca of the empire and as such was also used in the palace documentation. Hardly anything survived from this documentation. ${ }^{14}$

14 Three leaves of an ivory writing board originating from the Northwest Palace in Kalhu represent a rare remnant of a wax tablet: see Oates and Oates (2001), 104, Fig. 62. 
Lastly, internal matters do not generally seem to have been communicated in a written form but were probably conveyed verbally. The preserved documentation does provide an idea of how the communication worked between the king and his state officials active all around the empire and beyond. These officials kept frequent contact with the king via letters and came to visit and make report to the king at regular intervals. The way this state correspondence was handled, from the assumed dictating of a draft letter to the reading out before the recipient, remains mostly unknown. Despite a few references, the letters generally uphold the notion of direct communication and do usually not mention the scribes and secretaries that must have played an important role in organizing communication inside and outside the palace.

\section{Entering the palace}

It was not easy to seek access to the king in his palace in Neo-Assyrian times. However, it must have been easier for a royal magnate paying one of his regular visits to the king than for a low-ranking temple-smith seeking to petition his monarch. ${ }^{15}$ Both men, however, approached the palace through the same route. Both had to go through the main entrance of the palace, leading to the forecourts and from there to the gateway of the throneroom courtyard (Fig. 3). ${ }^{16}$ Access to the king's presence was controlled by a series of checks and controls, manned by different kinds of palace staff, from simple security personnel to different high-ranking officials. These court officials stood at the most important thresholds between the outside world, the palace and its monumental core, both metaphorically - by controlling the flow of people and goods in and out of the palace - and physically, as they were present within the main gates of the palace.

15 For the Neo-Assyrian period seven highest ranks of state including the commander-in-chief (turtānu) and the great treasurer (mašennu rabiu) have been identified. They were studied by Mattila (2000).

16 The forecourts of the Northwest Palace remain conjectural, but their presence is supported by the architecture of subsequent royal palaces, see Kertai (2015), 24-25. 


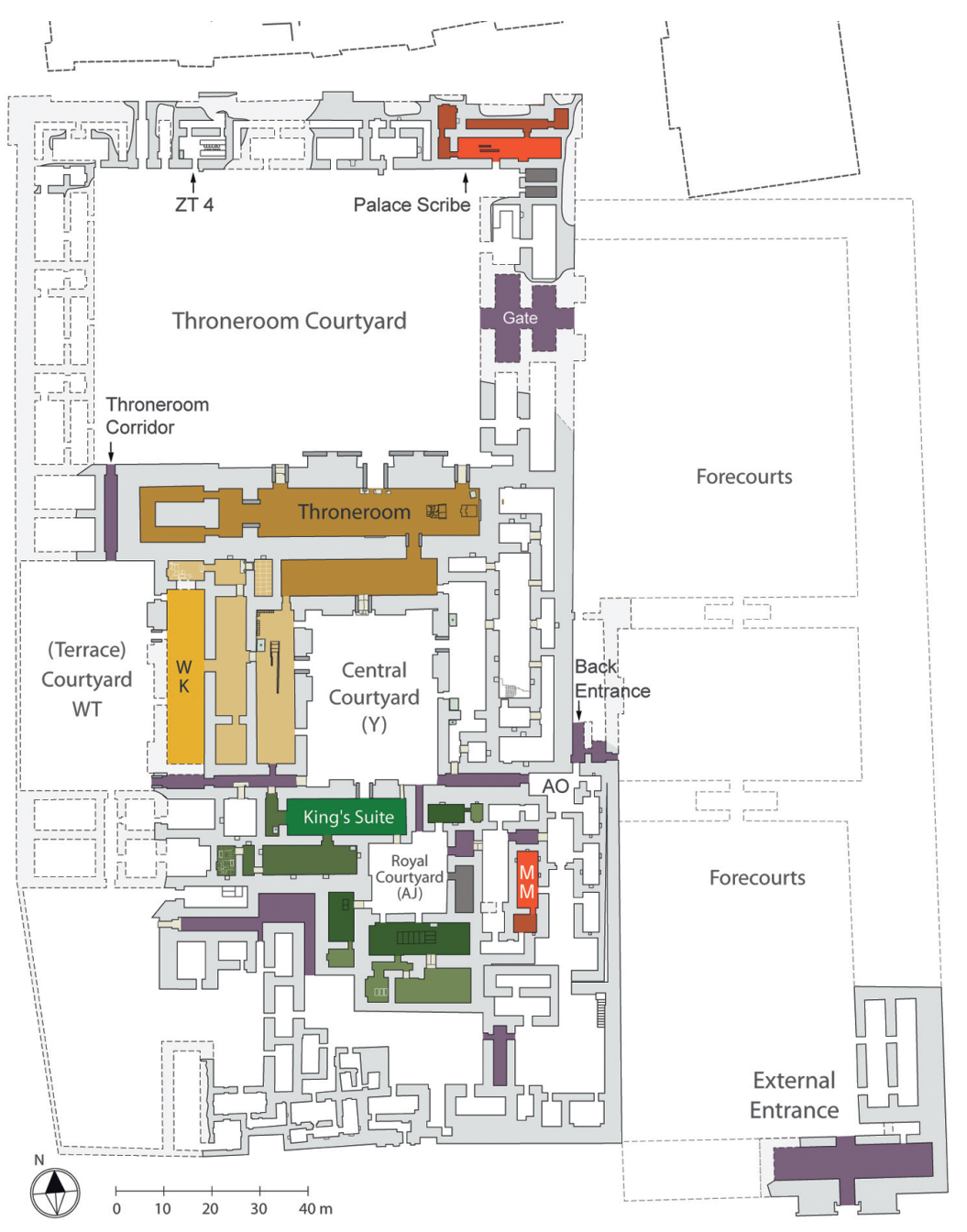

Figure 3: Northwest Palace in Kalhu as model for the spatial organization of an Assyrian royal palace (by D. Kertai).

The external gate of the palace consisted of one large room protected by apotropaic statues. ${ }^{17}$ This entrance gate provided access to the forecourts and allowed

17 Archaeological examples: rooms NW 17 and NE 46 of Fort Shalmaneser, Kalhu; room 98 of Sargon's palace, Dūr-Šarrukīn; and the reconstructed entrance into the Northwest Palace (Kalhu) through room 1 of the Central Building. 
people to proceed to the inner parts of the palace. The entrance gate formed a single entry point into the palace. It is the location with the most security-control. A primary check by the regular security staff is likely to have occurred within the gate itself, which provided ample space. The doorkeepers (atû) were often the ones to forward information to their superior or further inside the palace. In the Poor Man of Nippur, it is the doorkeeper Tukulti-Enlil who provides information about visitors to the house's owner. ${ }^{18}$ In a letter from Nineveh the smith of the household of the queen enquires whether the king has yet received the precious stones, which he had handed over to a doorkeeper along with an order for delivery (SAA 16 81).

The rab ekalli (palace manager) can be reconstructed as the supervisor of the external entrance and therefore as the likely superior of these doorkeepers. His responsibilities included overseeing the access to and egress from the palace of people and goods, as well as their circulation within the palace confines. ${ }^{19}$ More specifically, the rab ekalli was concerned with the handling of tax payments in kind. ${ }^{20}$ At the same time he controlled and set free people kept in custody by the palace (CTN 37 and 8). Titles like "palace manager of the Review Palace" (ekal mašarti) (CTN 3 10:3) and "palace manager of the Central City" (qabsi āli) (SAA 7 $115 \mathrm{i}$ 16) indicate that a separate palace manager was installed at each of the many active palaces situated near and far from the imperial center (SAA 7 115). This impression is corroborated by a reference to the rab ekalli ša Libbi-āle ("manager of the palace of the Inner City", that is, the main palace in the city of Assur), in the so-called "Middle Assyrian Palace Decrees" (MAPD), a set of decrees assigned to different kings, which were collected in the reign of Tiglath-pileser I (1114-1076). ${ }^{21}$

These decrees from the preceding Middle Assyrian period describe the practical responsibilities of the rab ekalli within the palace entryway. They show that the rab ekalli was the main official responsible for deciding upon the access to and egress from the palace. The rab ekalli, assisted by doorkeepers, was responsible for checking the palace personnel and the palace women and what they

18 Foster (2005), 932.

19 For instance, the palace manager bears responsibility over the delivery of grain (CTN 377) and is asked for the provision of reed (CTN 32). For the rab ekalli Isseme-ilī, see Pruzsinszky in PNA 2/I, 583 s.v. Isseme-ilī 2.

20 This included ilku payments of fodder, straw and flour (ND 3467, in Postgate 1974a, 399-400) and the delivery of bird fodder declared as iškāru material (CTN 310). This is documented in a legal record but the given terminology and the involvement of the deputy (governor) of Kalhu suggest that we are dealing here with an administrative procedure (cf. Dalley and Postgate 1984, 62) resulting from an obligation of silver for bird fodder towards the palace.

21 The MAPD are published in Roth (1995). The reference can be found in MAPD § 20; Roth (1995), 205. 
were carrying with them when leaving the palace (MAPD § 6). He gave permission to the royal ša rěši officials to enter the palace (MAPD § 9). These officials had dedicated their lives to the king for whom they fulfilled numerous roles. Their status was signaled by the absence of a beard. The rab ekalli is described as having stood at a particular entrance (specification lost) as long as the royal ša rēši lingered in the palace (MAPD § 9 ina pi [...] izuzzu). Furthermore, the rab ekalli was responsible for the inspection of royal courtiers (mazzāz pāni ša šarre ${ }^{22}$ ) and palace personnel (širku ša șābe ekalli) before they entered the palace. ${ }^{23}$

Although this information emerges from Middle Assyrian sources, it is compatible with sources from the late Neo-Assyrian period. A single letter or memorandum dating to the reign of Esarhaddon hints at the idea that the rab ekalli was in charge of providing access to the palace for palace members and their relatives. SAA 1650 is addressed to the rab ekalli and lists 14 individuals, including the wife of the rab ekalli, members of the family of the chief scribe (rab țušarri) Nabûzēru-lēšir and courtiers (mār ekalli), as "enterers" (erībūte). ${ }^{24}$ This text probably shows the privileges that could accrue to the family of important officials, although we do not learn about the precise location of the entrance. However, it would make perfect sense - also in view of the Middle Assyrian evidence - if this is about the main entrance to the palace.

The palace manager's proposed physical presence at the palace gate is corroborated by his frequent occurrence as a witness in legal transactions. ${ }^{25}$ The fact that doorkeepers are also attested with great frequency as witnesses supports our assumption that palace managers were active in legal transactions which took

22 For a discussion of the mazzāz pāni, see Groß and Pirngruber (2014), 161-175. They examine the semantic similarity but also the diverging usage of the terms ša rēši and mazzāz pāni especially in the Neo-Assyrian sources. While among the group of mazzāz pāni we find ša rēši, not all ša rēši were mazzāz pāni. At the same time not all members of the mazzāz pāni group were ša rēši. Apparently both beardless courtiers ( $\check{a} a$ rěši) and bearded courtiers (ša ziqni) formed part of the mazzāz pāni group. This assumption is also supported by the fact that ša rēši, ša ziqni and mazzāz pāni of the king are listed between the conjunction $l \bar{u}$ in the enumeration of possible transgressors against the crown (e.g. SAA 4 142:4).

23 Other officials mentioned as being responsible in this context are the nägir ekalli (palace herald), rabzāriqē ša hūle ("chief of the water sprinklers of the Processional Residence"), asû ša bètānu (physician of the inner area), ša muhhi ekallāte ša šiddi mātu gabbu (MAPD § 20).

24 For a discussion of mär ekalli being courtiers, see Groß (2014), 265-270.

25 For example, CTN339 r. 3; SAAB1 24 r. 2-3; SAA 1296 r. 17-18. In several instances he is the first witness - a fact which indicates his higher-ranking position. Gates of temples, palaces and cities were important places for jurisdiction and legal transactions in Mesopotamia throughout the millennia: see Ambos (2014-2016), 157-158; CAD A s.v. " $b a \bar{b} b u$ " 1.b.2, 1.c.4.a, 1.d.3.a. 
place at the palace gate. ${ }^{26}$ From his proposed position at the outer gate the palace manager could properly understand what was going on inside the palace and, at the same time, he could quickly get in contact with the environment of the palace and the representatives of other administrative spheres. Positioned at the threshold between the outer world and the palace, the rab ekalli maintained regular contact and dealings with provincial governors. These dealings fit well into the context of his area of responsibility of economic management of the palace. ${ }^{27}$ In one of his few preserved letters to the king, Ina-tešî-ētir, an official active in Babylon, hints at the relationship between these two officials by stating that he "will stay in the service of the governor and of the palace manager" (SAA 1733 r. 7-8). Contrary to the provincial governor, however, the palace manager was a purely administrative official who usually did not have a political role.

The palace manager had scribes (or secretaries) at his disposal, to aid with the fulfillment of his tasks. ${ }^{28}$ Even if he himself was not the commander of the keepers of the palace's main gates and other passageways as well as other personnel of the guard, ${ }^{29}$ he certainly cooperated with them in a close manner. In late NeoAssyrian times, he also worked together with the lock master (rab sikkāte) and other officials responsible for gateways and entrances (ša pān nērebi, sukkal nērebi) who emerge in the sources after the murder of Sennacherib and other conspiracies in the seventh century in order to strengthen the degree of security in the palace. $^{30}$ The palace managers were closely connected to other palace household members, including the palace scribe and the female personnel of the queen. They did business with each other (e.g. Edubba 10 5; ND 3425) and acted as witnesses in each other's business transactions (e.g. CTN 3 39). ${ }^{31}$

The sources support the proposition that the rab ekalli had the authority to decide by himself about goods and people that fell under his purview, while consulting with others as needed. These presumably included goods intended to be

26 Note also letter SAA 1688 reporting on herders who used to sell donkeys in front of the palace entrance.

27 For instance, the organization of work groups (SAA 199) and the handling of records (SAA 159). Also the aforementioned debt note concerning bird fodder which is due from the deputy (governor) of Kalhu (CTN 3 10) hints at the continuous professional interaction which the provincial governor and the palace manager maintained as the representatives of two different domains.

28 For instance, Rēmanni-Šamaš is twice attested as witness: SAA 1292 r. 8 and 94 r. 15.

29 A possible alternative candidate for this position - except for the rab sikkāte, ša pān nērebi and the sukkal nerrebi - was the rab atê.

30 Radner (2010), 279-280.

31 For the edition of ND 3425, see Wiseman (1953), 141. Sometimes, like in Edubba 10 5, business transactions show connections between different palace households which were located in different cities. 
used and stored in the forecourts. To move beyond the front gate, some form of permission must have been required. The status of "enterer" or a sealed document from the king (unqu) will have sufficed (SAA 8 157). ${ }^{32}$ The highest officials and royal family members will have been known well enough to receive automatic access, although this does not mean that they were not checked at the entry. Letters of invitation or letters including an explanation why the recipient needed to move further inside probably helped to receive access.

\section{The throneroom courtyard}

Entering the forecourts of the palace did not guarantee access to other areas within it. There was a second point of control, located at the entrance to the throneroom courtyard. This courtyard was centered on the throneroom, the most monumental space in each palace, which measured at least $500 \mathrm{~m}^{2}$. The throneroom was always the first monumental room to be encountered and signals the central role played by the king in his palace. The entrance into this courtyard was about interactions with the royal chancery, meeting the king and participating in court activity. The associated gate consisted of two large rooms. ${ }^{33}$ These gates will have been used as waiting area for visitors and as a point of control. Whether such control was performed by guards or other officials, the main responsibility must have resided with a higher official in charge of controlling access to the throneroom area. Gaining access to the throneroom courtyard brought visitors to the throneroom itself and the possibilities it provided for meeting the Assyrian king.

Numerous other suites surrounded the throneroom courtyard. A particularly well preserved example of such a courtyard was excavated in the Northwest Palace in Kalhu (Fig. 3). ${ }^{34}$ The office in the northeastern corner of the courtyard stood out for its size and can be associated with the official in charge of this area. ${ }^{35}$ The official that can be connected with this suite and whom we propose controlled

32 Cf. Frahm (1998), 120; Radner (2010), 280.

33 Archaeological examples: reconstructed eastern gate of the Northwest Palace, Kalhu; rooms NE 3/SE 13, Fort Shalmaneser, Kalhu; rooms 80-81, Sargon's palace, Dūr-Šarrukīn.

34 At least eight suites, excluding the throneroom which occupied the southern side of the courtyard, surrounded the courtyard of the Northwest Palace. Most suites were comparable in size and organization, consisting of a main room with one or two rooms behind it.

35 It was somewhat hidden and would not have drawn attention to itself. The suite was centered on a large room with an installation for heating during the winter. A small vestibule provided access to a bathroom. A narrow longitudinal room, behind the main room, gave access to another small space. In front of the main room was a small court with two storage-room like spaces. 
access at the gate into the courtyard is the tupšar ekalli (palace scribe) who, as Luukko has convincingly argued, was "head of the palace chancery" and "secretary of the state" in Assyria. ${ }^{36}$ This țušar ekalli was concerned with the recordkeeping for the palace (e.g. SAA 15 32) and, in doing so, kept track of the movement and installation of people (SAA 19 56), horses (SAA 7118 r. ii 3-14) and precious items (SAA 1361 ). The many letters, received by the palace scribe in the palace from his subordinates, point to their similar involvements and activities and support Luukko's general description. ${ }^{37}$ The number of letters addressed to the palace scribe is unsurpassed among the palace officials. This underlines his central administrative position within the royal palace and his extensive networks beyond.

The palace scribe and his bureau arranged the written communication of the king and his officials. Political and in part highly sensitive information passed through his office. The palace scribe was therefore well informed about state and domestic matters alike, although he was the middleman rather than the main addressee of these issues. This is also true in connection with letters from people from outside the palace who wanted to meet the king either to discuss state matters or to petition the king for personal reasons (SAA 16 82). The chancery produced sealed letters from the king (unqu) that gave the recipient permission to visit the king, while probably also being the intended destination. The woman Sāraia, for instance, addressed a letter to the palace scribe in which she asked for support on behalf of seven individuals who were treated wrongfully by the governor Marduk-erība and who demanded access, purportedly to the palace (SAA 16 49). Although Sāraia's status and connection to the palace scribe are unclear, it is noteworthy that she could intercede in order to arrange access. ${ }^{38}$

The use or occupants of the other suites surrounding the courtyard remain unknown and certainly changed over time. The number of suites could have been chosen with specific offices and uses in mind, but their number was not standardized. Some of the offices can be associated with the chancery. This is most evident in Room ZT 4 of the Northwest Palace, where state letters were found and which contained installations for storing of clay tablets. ${ }^{39}$ It is possible that the scribes and officials of the chancery took up the entire northern side of this courtyard. We assume that a number of scribes and other literate staff were at the dis-

36 Luukko (2007), 231, 235.

37 SAA 10 130; SAA 1648 and 49; SAA 1913, 14, 56, 123 and 124. Several of these letters also seem to deal with matters of the palace scribe's own household.

38 For a discussion of the hierarchical relationships presented in this letter, see Svärd (2015), 162164.

39 Oates and Oates (2001), 45, 197, Fig. 120. 
posal of the palace scribe in order to handle all the recording, bookkeeping and correspondence. These tasks also caused him to cooperate with the treasurer ( $m a$ šennu) (SAA 13 61) and the chief of accounts (rab nikkassi) (SAA 16 48), though these two officials did not necessarily have an office here.

Like the palace manager, the palace scribe was an administrative official who was, in principle, not directly involved in state matters. Evidence in state letters referencing the palace chancery clearly indicate that in practice the scribe and his chancery acted on behalf of the palace. Not every matter reached the king himself, and the scribe thus had some authority to decide on issues in the name of the palace. ${ }^{40}$ Furthermore, since the palace scribe and his chancery communicated about royal audiences and other palace visits beforehand, he will have been in close contact with the security personnel standing at the passageway to the throneroom courtyard next to his office. In some cases the scribe could therefore presumably make the decision to allow or prevent access to the king.

\section{The monumental center of the palace}

The central part of the palace was filled with monumental reception suites of which the throneroom was the biggest and the first to be encountered. These suites grew in size and number as the empire grew..$^{41}$ Numerous officials were responsible for what happened in these spaces. This included facilitating the different events for which these suites were intended, moving people and goods around and supervising the storage spaces and treasuries. No independent office-like suites are known from these parts of the palace. This did not mean that officials had no offices in these parts of the palace. The structure of the large suites, which all contained storage spaces and vestibules, was suitable for the use of officials. The suites, however, were organized around specific activities, rather than for the use of specific functionaries.

After having passed through the two gates, movement continued through corridors, which formed the main spaces of movement in the inner parts of the palace. There is a sequential quality to most routes, which can be associated with a decrease in ease of access. This sequence was, however, countered by the existence of alternative routes and the presence of back entrances which allowed the main sequence to be bypassed. This general movement was independent from the access to the individual suites, which occurred at the entrance of the suite itself.

40 Luukko (2007), 235.

41 Kertai (2015), 241-245. 
This meant that having access to any part of the palace did not need to include access to the suites located there, while also allowing for the access of a specific suite without providing access to any of the other spaces of the palace. The resulting connections were economic and flexible as well as easy to control.

The most important corridor was the one connecting the throneroom courtyard with the more inner areas of the palace (Fig. 3). This was the main route for visitors going further into the palace. ${ }^{42}$ Each corridor gave access to a specific courtyard. Despite their importance in providing access within the palaces, it remains unclear whether corridors could be closed off. ${ }^{43}$ The absence of doors would not of course mean that movement was unrestricted, but that control was centered on individuals guiding movement and guarding individual doors. There is, however, an argument to be made that access was primarily controlled at the entrances of the suites rather than the routes between them. Although doorkeepers (atû) and guards (ša mașșarti) could have stood at fixed locations, they were not associated with specific areas, rooms or doors in the known texts. There is, for instance, no attestation of a guard of the throneroom or bedroom. A distinction is once made between the doorkeepers of the outer palace area (qannu) and inner palace area (bētānu), ${ }^{44}$ but this distinction is not found in the administrative texts. As proposed above, the doorkeepers of the outer area are likely to have been associated with the rab ekalli.

One official responsible for access to the royal realm was the ša pān ekalli (literally "the one in front of the palace") and commonly referred to as "palace supervisor" in secondary literature. His activities suggest that the palace in his title acted as a metonym for the king and hence will be referred to as "supervisor of courtly activity." This official is first attested in the reign of Adad-nērāri III and

42 Archaeological examples: WZ in the Northwest Palace (Kalhu); S76, Fort Shalmaneser (Kalhu); rooms 13/15, Palace F (Dūr-Šarrukīn), rooms X/35 as well as 10, Sargon's palace, Dūr-Šarrukīn. None of these corridors was preserved well enough to know whether they possessed an external door originally, although it is difficult to believe they would not have been closable.

43 Although wooden doors do not tend to survive in the region, their original presence is generally indicated by the presence of pivot stones. The older excavation, such as those in Nineveh, did not consider such installations worth mentioning. The presence of doors can sometimes be reconstructed through the presence of a recess in the adjacent wall. These were, however, only found in corridor 12 of the Southwest Palace. The shift in the wall of corridor 42 might also indicate the original presence of a door, but its location in the middle of the corridor is atypical. Information about the palaces of Dūr-Šarrukīn is lacking except for the southern side of corridor X, which did not have a pivot stone. No pivot stones were found in the corridors excavated in the Northwest Palace in Kalhu. The evidence is quite different for Fort Shalmaneser, as pivot stones were present in most internal corridors.

44 See the queries to the sungod Šamaš SAA 4 139, 142 and 144. Kertai (2014), 196. 
therefore might have been introduced only after the reign of Aššurnașirpal II. Although he appears at first glance similar to the rab ekalli, his functions and rank were quite distinct. While the rab ekalli was part of the palace's staff, the ša pān ekalli was a political figure. As such he arranged the loyalty oaths to the king (e.g. SAA 1 76) and went on military missions in Babylonia (e.g. SAA 18 202; ABL 521).45

The ša pān ekalli was the primary attendant of the king. He was one of the main decision-makers when it came to the question of whether officials and Assyrian allies were granted an audience with the king or not (SAA 13 80; ABL 287). As Barjamovic puts it, he was the "introducer to the king and chief of palace protocol." ${ }^{" 46} \mathrm{He}$ accompanied the king during the performance of rituals (SAA 20 18) and introduced high-ranking officials to the king on special occasions such as banquets (SAA 20 33). According to this rare protocol of a royal banquet, the ša pān ekalli was the second to enter the banquet after the king. It was his task to bring in the high-ranking state officials and royal princes (SAA 2033 i 419). The ša pān ekalli acted as the main protocol master. He told the cupbearer (šâqiu) to pour drinks (SAA 2033 r. i 46'). The ša pān ekalli was supported by the chief cook (rab nuhatimmi) who announced the end of the banquet (SAA $2033 \mathrm{r}$. i $\left.48^{\circ}-49^{\prime}\right)$. He and the $r a b$ ša rēši had the privilege to serve the king food (SAA 20 33 r. i $\left.32^{\prime}-36^{\prime}\right)$.

In contrast to the rab ekalli, the ša pān ekalli was not involved in the everyday business of the palace household, but played a major role within the political hotspot formed by the immediate environment of the king, independent from the latter's actual whereabouts. This becomes clear from the fact that the "supervisor of courtly activity" - unlike the palace manager - was not assigned to a specific palace and only in the seventh century was he assigned to specific courts (in addition to the one of the king, those of the king's mother, the queen and the crown prince).$^{47}$ His responsibilities were contextual rather than being correlated to specific places of control. If the ša pān ekalli possessed an office in the palace it is likely to have been close to the throneroom, the place most directly associated

45 For ABL 521, see de Vaan (1995), 270-274. His involvement in Babylonia is especially evident for the seventh century when Babylonia was (though not without turmoils) under Assyrian control.

46 Barjamovic (2011), 40.

47 E.g. SAA 1296 l.e. 3; SAA 75 i 36; SAA 18101 r. 7-8. Note, however, the occasional occurrence of the title LÚ*.šá-IGI-É.GAL.MEŠ (SAA 13 80:14; SAA 4 142:8 and 144:8). Its literal meaning "the one in front of the palaces" would support the idea that the ša pān ekalli was not connected to a specific palace. Note also the aforementioned ša muhhi ekallāte ša šiddi māte gabbu, "administrator of all the palaces of the entire expanse of the country" in MAPD $§ 20$ (Roth 1995, 205). However, in view of the fact that in the seventh century ša pān ekallis were also appointed to domains other than the royal court, these references might need to be translated as "palace supervisors," thereby emphasizing the plurality of ša pān ekalli. 
with encountering the king, but not necessarily close to the courtyard's entrance. ${ }^{48}$ Such hypothetical location would suggest that the ša pan ekalli shared responsibility in controlling the gate into the throneroom courtyard. His involvement would however have been more situational, depending on his and the king's presence and the associated activity.

\section{Tribute}

Once people were granted access to the king, there were several kinds of events in which they might be involved. Some of these are depicted on palace reliefs and various other media. The most commonly depicted events are those in which foreigners, tributaries or prisoners bring goods to the king or visit him themselves (Fig. 4). A second type consists of Assyrian officials bringing loot or objects otherwise procured. In depictions of these events, the king is usually portrayed standing, but can also be shown seated (especially when on a military campaign). The iconography sometimes shows the events to have taken place during a military campaign, but does not show an architectural setting otherwise. The encounters could have taken place anywhere inside, or even outside, the palace. The most elaborate setting for a throne was created in the throneroom, but similar settings occurred in other rooms and courtyards as well.

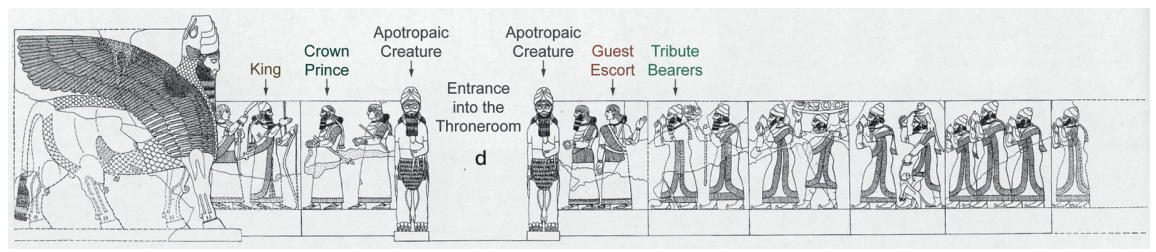

Figure 4: Drawing of the reliefs on the façade outside entrance $d$ of the throneroom of the Northwest Palace in Kalhu (after Meuszyński 1981, Tf. 5).

At least iconographically, these encounters were standardized, following protocol that appears to have changed little over time. The same type of people is

48 Room EB in the Northwest Palace is among the more strategically located rooms, being placed between the main entrance into the throneroom courtyard and the exit of the throneroom. It was a representative room which had been decorated with geometric wall paintings. The second room of the suite (Room EC) is more likely to have been a storage room due to the fact that its door could be closed from the outside. The location and monumentality of the suite fits with the duties of the $\check{a} a$ pan ekalli. 
shown performing the same roles. A beardless courtier, who raises his hand in a halting gesture, escorts the groups and makes them stop in anticipation of their meeting with the king. This official is likely to have picked up the group at the one of the main gates of the palace. As a beardless man, he belonged to the category of courtier called ša rēši.

The actual task of introducing people to the king was associated with the crown prince in iconography. This role is, however, idealized and was not based on historic circumstances. The crown prince was shown in settings regardless of whether the empire had a crown prince at the time. ${ }^{49}$ Differing from these idealized images, textual sources give the ša pān ekalli a prominent role when it comes to escorting people and introducing them to the king. There is, however, no indication that the ša pān ekalli was of ša rēši status, making it unlikely that he is depicted with raised hand standing in front of people. Textual sources also indicate that the crown prince could take over the king's role in receiving tribute, in the king's absence. ${ }^{50}$

In visual sources, the crown prince is generally accompanied by up to six courtiers standing before the official escorting the rest. That these represent high officials is indicated by their closeness to the king and the fact that they do not need an escort to move through the palace. It is only their position that separates them from the other officials. They are not distinguished by their clothing or apparel. These courtiers likely represent the special group of mazzāz pāni, which maintained a particularly close relationship to the king. Strikingly, they are always shown as a combination of bearded and beardless courtiers, suggesting an equivalency between both groups. ${ }^{51}$

The king himself tends to be accompanied by a few beardless courtiers. These can be separated into three types. Behind him stand one or two weapon bearers as his personal guards. Their most common weapon is the bow and arrow, which must represent a sign of office as it cannot have been very helpful in protecting the king at close distances. These guards likely belonged to the royal bodyguard called ša šêpe, literally "(he) of the feet (of the king)." 52 The two other types of

49 Kertai (2017).

50 E.g. according to the letter SAA 129 the crown prince Sennacherib received, sealed and deposited the tribute brought to Kalhu by the Ashdodites.

51 Compare with the brief discussion in fn. 22 above. Note that the expression "the ša rěši who bear arms (tillu) and 'the bearded ones' (ša ziqni) who bear arms and stand guard (ana mașșarti uzuzzu) for the king" (SAA 4142:12 and 144:12) possibly refers to the same group of officials.

52 See the detailed description of the written evidence in Dezső (2012), 120-123. According to Dezső, ša-šêpe do not appear in a "position of trust" as is the case for their much more frequently attested counterpart of ša-qurbūti who are well known for the delicate missions they had to fulfill throughout the empire. However, the less frequent occurrence of ša-šēpē could be explained by the 
courtiers stand ready to serve the king. One is carrying a parasol, while the other is carrying a towel and fly whisk. Although the parasol-bearer is depicted frequently, the function is not provided with a specific title in Assyria. These figures could each belong to the ša bēti šanie. The ša bēti šanie were also the main attendants in the protocol of the royal meal (SAA 20 33). They were responsible for the incense and fire, provided water for hand-washing, used a whisk and a wooden box for keeping the dining room clean and held torches at night. In general they were present and ready to serve. ${ }^{53}$ The same text also contains a single attestation of the ša bèt kāșiri who stands ready to receive dirty towels and to give out new ones (SAA 20 33:16-19). This is another possible candidate to have been depicted as royal attendant with towel and fly whisk.

Another possible way to identify these royal attendants is offered by the enumeration of officials in queries that had been submitted to the sun-god to ask about possible rebellions against the crown. Here, the ša pān ekalli is mentioned together with the ša huțāri (staff-bearer) and the ša mașșarti (guard) between the conjunction $l \bar{u}$ (e.g. SAA 4 142:8). This is a hint that the three worked closely with each other or that the significantly higher-ranking ša pān ekalli was supported in fulfilling his tasks by the ša huțāri and the ša mașșarti. As a consequence, the weapon bearers behind the king could instead represent the ša mașșarti, and those carrying either a parasol or a towel and a fly whisk, the ša hut țāri. ${ }^{54}$

\section{Audiences with the king}

One of the main activities that took place within the palace's internal areas was the royal audience. As the letter by Nabû-šumu-iddina, mayor of (or working on behalf of) the Nabû Temple, ${ }^{55}$ highlights "the face of the king my lord has been seen by very many (people)" (SAA 13 80:11-13). Indeed, the royal audience was one of the central activities at the Assyrian court, and served to allow regular

likely scenario that they were the king's steady companions and hence their tasks were usually communicated orally, in the direct environment of the king; cf. Groß (2014), 615-617.

53 This is expressed by the phrase ina mașșarti uzuzzu; see CAD/M1 339 s.v. mașșartu 6a: "duty, service [performed] ... in the palace" and cf. the discussion about mașșartu in Baker and Groß (2015), 80-81.

54 More than one solution is applicable since overlaps concerning function and tasks did presumably exist and also since the title ša šêpe (like the titles ša rēši and ša ziqni) was a class designation and, hence, could be borne by officials in addition to other titles.

55 The title of Nabû-šumu-iddina is not attested in this letter, but he points out that he is hazannu ša bit Nabû in another letter of his (SAA 13 78:12); cf. Baker in PNA 2/II, 855-856 s.v. "Nabû-šumuiddina" 15. 
visits from high officials as well as scholars to the king. These visits happened not only because these officials and scholars sought audiences with the king, but also because their regular appearance at court was demanded by the king in order to deliberate on state matters and personal matters alike. Lower-ranking subjects of the king were only granted irregular or exceptional audiences with the king. Lacking almost any hint on the actual location of royal audiences, the throneroom is assumed as the main place of action. It is the most monumental space of the empire, which was designed to impress and geared towards leading people towards the king seated at the end of the room on his throne. ${ }^{56}$

At least on occasion the king favored to meet his officials in groups (SAA 15 24). Being present did not, however, automatically lead to being heard. Bēl-iqī̌sa's case was not discussed when he came to an audience, leading him to write a letter to the king later (SAA 17 27). Assurbanipal blames the governor of Nippur and the ša pān ekalli for not allowing an entire delegation of elders to have entered into his presence: "By Aššur, my God, I swear that I did not know that only half of your number had entered before me. How should I know who is who?" ${ }^{57}$ The elders had apparently been unable to address their partial exclusion in the king's presence and had therefore written a letter when the audience was over (ABL 287). These details indicate the formal organization of such encounters. According to another letter the messenger of the official Bādāia missed the audience altogether, because of delays, and returned home with the report he had been carrying for the king (SAA 17 101).

The quantity and quality of contact which the king granted to his subjects was essential for the standing and reputation within the Assyrian state apparatus. The higher the frequency of visits, the higher was usually the status and authority of a person. At the same time, it makes a difference whether a provincial governor came to the palace to report and discuss issues of his province and military operations, or whether one of the king's scholars met the king to inform him about omens and to talk to him about his well-being. The two groups maintained a very different approach towards the king.

The state officials had a professional relationship with the king and used nononsense language in their letters to the king. Due to the fact that they were active abroad and distributed all over the empire, the exact date of their visit was set in advance. The governor of Bït-Zamāni (Šarru-ēmuranni), for instance, proposes Tammuz 15 to the king (SAA 5 47). The king also used these occasions to clarify disputes (SAA 19 89) and appoint new officials (SAA 175). The regular meetings

56 Winter (1983); Porter (2003).

57 Barjamovic (2011), 41. 
with his officials were part of the administrative ethos and helped the king to keep control and bonds tight. The delayed appearance at court or the non-observance of appointments with the king were only accepted with good reasons such as roads being blocked by heavy snowfall (SAA 15 83). The formality of these encounters fits well with the ceremonial setting of the throneroom.

The king's entourage also consisted of a diverse group of scholars who provided the king with advice, but whose relationships were based on patronage. ${ }^{58}$ Since the scholars stayed in the vicinity of the king and his palace, meetings were often arranged at short notice and could, if necessary, happen at short intervals. Visits to the king were scheduled for "tomorrow" (SAA 10 322) or "the first day he is unoccupied" (SAA 10 69). Others were told, however, to visit twice a year (SAA 10 371). Even if the scholar was unable to visit the king, written reactions to the king's problems, questions and requests seem to have been expected immediately. The chief physician Urad-Nanāia writes that he had not been able to diagnose the king's ailment when he had stood before him. He asks for his subsequent diagnosis and solution to be read out to the king and promises to come to the palace to give further instructions (SAA 10 315). ${ }^{59} \mathrm{~A}$ letter by Balasî, known to have been the master scholar of the crown prince Assurbanipal (SAA 10 39), was read to the king without Balasî's presence, but was not understood by the scribe (SAA 10 60) nor presumably by others present including the king. Balasî promised to explain the content himself the "first time that I come before the king." In another instance Balasî writes to the king to let him know that noted scholar, and priest of the Aššur Temple, Akkullānu, ${ }^{60}$ "will read and explain [the rep]ort on the lunar [eclipse] [be]fore the king” (SAA 10 57). Telling the king that something was complicated was a common tactic to receive a request or permission to come to the palace and explain the issue in person (SAA 10 60; SAA 10 276).

The king had regular meetings with the scholars about intimate and state matters alike. Since scholars maintained a comparatively personal and therefore a less stable relationship with the king, they themselves show a considerable effort to meet the king. The personal tone in their letters indicates a greater dependence on the king and the higher likelihood of being excluded from the inner circles of the royal court. Letters in which scholars complained about not been able to see the king were common (SAA 10 226, SAA 10 294). The letters showcase a palpable fear of falling out of grace and the loss of patronage this entailed. The

58 Radner (2011b). In this article she compares the relationship between the high-ranking officials and their king with the relationship between the scholars and the king.

59 For the chief physician Urdu-Nanāia, see Radner in PNA 3/II 1411 s.v. Urdu-Nanāia 2.

60 Pearce and Radner in PNA 1/I, 95-96 s.v. Akkullānu 1. 
king could relatively easily and quickly decide about exclusion from the inner circles, which meant a bad fate, a fate often described as the life of a dog or death (SAA 13 190; SAA 17 53; SAA 18 73). ${ }^{61}$

Basically everyone was entitled to petition the king and seek help. ${ }^{62}$ In comparatively rare cases the king is indeed attested to have met other people like a carpenter, who acted as a representative of a group of carpenters (SAA 196). The more and the better the connections to the palace household and its personnel, the higher were the chances to actually approach the king and seek for support. Having a family member or someone else inside the palace would certainly have been beneficial (SAA 13 178). A lack of such support limited one's possibilities to react against others slandering your name within the palace (SAA 17 53).

Independent from whether high- or low-ranking individuals met the king, the ša pān ekalli will have presided over and decided upon the accessibility of the king and introduced the royal subjects to their king. In a letter to the king, the mayor of Aššur Temple asks whether the ša pān ekalli can make him see the face of the king (SAA 13 80).

Except for meeting the king personally, officials and other subjects of the king tried to get in contact with the king or stayed in contact with him via written messages. In these cases messengers were sent to the palace in order to forward the letters (SAA 18 119) and to send greetings to the king (SAA 18 146). The king often received information from multiple sources which could be corroborated against each other. An example of this is the military commander Bēl-ibni, who sent a report about political developments in the east, but also sent back Iqī̌sa, a servant of the king, who was described as being able to corroborate Bēl-ibni's narrative (ABL 280). ${ }^{63}$

Presumably the king did not meet these people, but heard their delivered messages from the mouth of the scribes working in the palace chancery or the palace scribe himself (SAA 10 60, 373; SAA 8 316; SAA 18 124). In one letter the responsible scribe is fittingly asked not to hide the message from the king (SAA 16 32). In case astrological reports arrived at court, they were received and introduced in the presence of the king and read to the king by a man who was known by the king (SAA 10 76). Drawing a parallel from this protocol, we assume that the

61 However, the scholars' high degree of literacy and their ability to apply a more developed writing style, might at least partly be the reason why their letters let them appear much more personally involved than other members of the court.

62 This is clear from the precept "to speak the word of the king” (abat/amat šarrizakāru/qabû); see Postgate (1974b).

63 See for this letter de Vaan (1995), 239-241. 
king did usually not read letters addressed to him and that the reach of a written message depended to a great extent on the scribe who handled it. ${ }^{64}$

\section{The inner parts of the palace}

On the edge of the palace's monumental area was located the king's suite, an elaborate reception suite reserved for the use of the king, his family and his most trusted officials (Fig. 3). The other residential suites of the palace tended to be located nearby. ${ }^{65}$ We know less about the function of these suites, because they rarely appear in the preserved documentation. No specific official was responsible for the king's suite, just as other suites do not seem to have possessed their own specific officials. Officials, such as the ša pān ekalli, who organized access to the king, must have controlled the entrance into the king's suite. The monumentality of the suite, and its large size, makes it suitable to receive people. Such meetings might have been restricted to the king's own officials, for instance during morning visits to report on the day's business.

The royal family also resided in the inner parts of the palace. The royal offspring possessed their own servants and tutors while living in the palace, but they moved out of the palace after having reached adulthood. Both the crown prince and the queen had their own extensive households. ${ }^{66}$ Their officials visited the palace to report on and discuss their duties. The banquets, gifts exchanges and other ceremonies that were associated with large households, such as those of the queen, must also have taken place in the palace. The inner parts of the palace contained monumental suites to accommodate such events and meetings. ${ }^{67}$ The crown prince had his own palace in the seventh century. ${ }^{68}$ The queen is thus likely to have been the most active person in these parts of the palace. The queen's $\check{a} a$ pān ekalli is likely to have had his office in the monumental, but mostly unknown,

64 Note therefore also the letter SAA 166 in which its lost author states that he neither opens nor reads letters addressed to him and that this is done by his reporter (bèl țēmi) instead. The fragmentary letter has been put in the mouth of Esarhaddon, but - although it must be a high-ranking person - this attribution remains doubtful: see Luukko (2007), 231, n. 18.

65 Kertai (2015), 227-229.

66 For a detailed discussion of the personnel of the queen, see Svärd (2015), 61-74, and for the crown prince, see Groß (2015), 251-266.

67 Their occurrence seems supported by the presence (at least in the seventh century) of a ša pān ekalli. A ša pān ekalli is known for the crown prince during the reign of Esarhaddon (SAA 18101 r. 78) and Assurbanipal (SAA 6328 r. 7). A ša pān ekalli of the queen is attested in a letter dated to the reign of Sīn-šarru-iškun (SAA 1296 l.e. 3).

68 Kertai (2015), 149-150. 
inner area of the Southwest Palace in Nineveh. A nearness to the queen seems a prerequisite for his job. Tāab-șil-šarri, the ša pān ekalli of the crown prince during Esarhaddon's reign, had his own house outside the palace, as it is there that people are described as assembling and inciting each other (SAA 18 101) ${ }^{69}$

The monumental route could be avoided by using a backdoor that provided direct entrance into the inner parts of the palace. Most goods and many visitors are likely to have entered through this passage. This route could be taken by the officials working in the inner parts of the palace, the officials associated with the queen, royalty residing in these parts and people delivering goods to them. Their access could be controlled at the door of these back entrances. The back entrance of the Northwest Palace provided access into courtyard AO and is among the few such entrances to have been excavated. Room 74 similarly acted as a back entrance into the inner areas of Sargon's palace, but its surroundings are poorly understood. ${ }^{70}$ The seventh-century palaces possessed much more monumental back entrances that took the form of descending corridors. These could accommodate more ceremonial processions as well.

The back entrance of the Northwest Palace indicates the advantages of such passage. It created a quick route into the monumental central part, the adjacent residential area as well as the back part of the palace. A suite centered on Room MM was located close to this entrance. The official located here could control and organize the inner parts of the palace including its monumental center and residential parts.

The ša muhhhi bètāni (chamberlain, “(he) who presides over the inner area”) is a good fit for such job description and location within the palace. ${ }^{71}$ According to the literal meaning of $\check{s} a$ muhhi betāni, this official supervised the internal processes of the palace household..$^{72}$ Information on his duties is, however, limited and therefore his association with the back entrance of the palace remains tentative. One of the reasons why we hardly find him in the sources might be that the

69 This Babylonian letter rather reports on circumstances in Babylonia and refer to the ša pān ekalli of Šamaš-šumu-ukīn, designated king of Babylon, than to his brother Assurbanipal, designated heir to the Assyrian throne.

70 Kertai (2015), 101-102.

71 Both the title ša muhhhi bètāni and the term bētānu are rarely attested in the Neo-Assyrian sources and the attestations we have are not very informative. An exception is the letter of Bēl-iqīša who reports to the king that the scribe of the major domo ( $r a b$ betti) has menaced him to cut him from the bìtānu (SAA 16 112). Hence, Bēl-iqī̌sa was threatened with the possible restriction not to be allowed anymore to enter the inner area (of the palace).

72 The Babylonian letter SAA 18121 which shows him in charge of sealed storehouses (bit kunukki) containing food supports this. 
available documentation does not highlight the internal procedures and circumstances of the palace.

\section{Conclusion}

The Neo-Assyrian Empire forms one of the earliest experiments in how to rule a large heterogeneous territory. Being the first kingdom to reach such scale in the region, many of the tools to organize the royal court had yet to be created. The changes entailed in becoming an empire will undoubtedly have influenced the spatial organization of the Assyrian court and the roles of its different functionaries. Although the increased size of the court and its palaces is easily correlated with the increased size of the empire, the general architectural model presented here seems to have been remarkably stable from the reign of Aššurnașirpal II (883-859), the first time it can be detected, till the end of the Assyrian Empire in c. 612. The written sources reflect the architectural model at latest from the reign of Adad-nērāri III onwards, whereas especially the office of the rab ekalli and its principal responsibility of the management of the palaces is already traceable in the Middle Assyrian sources.

We argue that the Assyrian court used two different ways to organize itself. One system focused on the flow of information, goods and people entering the palace and can be described as the "thresholds court." It was administrative and centered on specific spaces of control. It organized the different flows into three different realms, centered on different palatial gates. We suggest that the outer gate was the domain of the rab ekalli (palace manager), an administrative function that involved organizing the access to and egress from the palace of goods and people. It was a location and function that entailed interactions with the direct vicinity of the palace. The managerial role of the rab ekalli is likely to have been more expansive when the royal court was not in residence. In other palaces, where the royal court did not normally reside, he seems to have been responsible for the entire complex. The gate of the throneroom courtyard, and thereby the rest of the palace, can be associated with the tupšar ekalli (palace scribe) and the chancery headed by him. The chancery checked the flow of people and information coming from all parts of the empire into the palace. To facilitate more easy access to the central and inner parts of the palace each palace possessed a back entrance. We propose that the supervision of this entrance was the task of the ša muhhi bètāni (chamberlain), since the literal meaning of his title and the available written sources indicate an involvement with the internal activity of the palace household. These three officials are likely to have divided the responsibilities for the flow of goods, people and information into and out of the different parts of the 
palace. Their roles fit well with the three main thresholds that typified the architecture of Assyria's royal palaces.

The three thresholds and administrative realms were relatively stable over time. The letters, however, highlight that the functions were never strictly separated or codified. People were able to look for support through whomever seemed most amendable to their plight. This explains letters in which other, higher-ranking officials are asked to intervene. ${ }^{73}$ The association of different officials with different areas of the palace raises questions of departmental overlap and conflict, which cannot be solved at the moment. The model presented here is flexible but also sequential, implying that people had to pass through the rab ekalli before the țupšar ekalli or ša pān ekalli could be reached. This could have given the rab ekalli the ability to refuse entrance regardless of the opinions and wishes of the officials further inside. Such problems might have been avoided through strict separations of responsibilities, but our sources do not indicate that strict separations existed. ${ }^{74}$ Most officials moreover had responsibilities and interests beyond their primary location within the palace. ${ }^{75}$ Meeting the king or sending him letters were similarly formalized and open to manipulation. ${ }^{76}$

The second system was more political and organized the activity taking place in the palaces. This system was more flexible and situational and can be described as the "itinerant court." This system of control was not about specific spaces, but was organized around activity taking place in the palace and followed the king wherever he was. The itinerant court was supervised by the ša pān ekalli ("supervisor of courtly activity"). He could have possessed his own office in the throneroom courtyard, but his primary location was with the king, a responsibil-

73 Examples include the official Bēl-ibni's letter to the rab ša rēši, who belonged to the highestranking state officials, seeking the favor of the king (SAA 17 53). Another example is the letter to the scribe of the ša pān ekalli, which deals with a command of the local governor not to sell donkeys in front of the palace entrance (nērebu) at Nineveh (SAA 16 88). It is not the expected rab ekalli who is involved, but rather the ša pān ekalli. It would seem that the donkey-herders believed that this scribe provided their easiest and best attempt to plead their case in the palace possibly because the ša pan ekalli - as a principal member of the royal court - was higher-ranking than the locally active rab ekalli.

74 The aforementioned letter SAA 1650 can be interpreted as a written order given to the rab ekalli as to whom he has to grant access to the palace.

75 The horses received by the palace scribe (SAA 7 118), for instance, are unlikely to have been kept in the throneroom courtyard where this official held office. The storage facilities, which concentrated in the forecourts, and the treasuries, which were more frequent in the inner parts of the palace, are likely to have been used by several officials.

76 The scholar Urad-Gula sent his letter through the ša rēši Šarru-nūrī (SAA 10294 r. 3), although this could merely mean that Šarru-nūrī brought it to the appropriate official such as the țupšar ekalli (palace scribe). 
ity that continued outside the palace when the king was on the road. Spatial compartmentalization did not play an important role in how the main part of the palace was organized. Neither public or private form relevant concepts when it comes to the palaces of Assyria. The main parts of the palace did not have proper gates but were organized through a series of corridors, which connected the different courtyards from where the different suites could be entered.

The most important of these suites was the throneroom. It was easiest to reach, and with its massive size and elaborate decoration, geared to accommodate large groups in the most impressive setting to be found in the empire. It is here that most people presented themselves to the king, bringing their tribute, problems, explanations and excuses. Visual and textual sources suggest that these encounters were formalized, sometimes leading to information being lost through the inability of people to get themselves heard or even receive the promised access.

Behind the throneroom a series of monumental suites existed, which were also large in size and sumptuously decorated. These suites increased in size, monumentality and importance over time as the empire grew in size and complexity. The large banquets, ceremonies and other events for which these suites were intended were formal in their organization and included some of the same people, such as provincial governors, foreign dignitaries and other high officials. The palaces also contained suites that can be associated with sleeping, but their architecture and decoration suggest that they were intended for similar official activity as to the other large suites.

The "itinerant court" was centered on the king, whose accessibility was flexible and contextual. The king, and activity involving him, was not restricted to the palace let alone to specific parts within the palace. The Assyrian court followed the king and depended in its organization on the activity and situation at hand rather than on location. The king was surrounded by different types of officials who organized the different events that the king partook in. These included foremost his royal attendants who continuously accompanied the ruler for the sake of his security and well-being. Meetings between the king and his officials and scholars are the most flexible category when it comes to their location and formality. The letters indicate that the king was informed frequently, which suggests that he was informed wherever he was in the palace or outside of the palace (e.g. in the military camp). Officials were not bound to specific rooms, but were to some extent flexible in performing their tasks at the required place. A separation can be reconstructed between those that were allowed to move around the palace relatively freely, i.e. the mazzāz pāni, and those that needed to be escorted.

As the Assyrian royal court set out to collect the world on an unprecedented scale, its palaces introduced two fundamentally different modalities to organize 
the royal court, which can be described as "thresholds" and "itinerant." This general organization was already present in the architecture of the royal palaces of Kalhu during the ninth century and seems to have remained in place up to the end of the empire. The court of thresholds was mostly administrative in nature and organized the flow of goods, people and information into three administrative realms centered on their respective thresholds. The itinerant court was about activity and therefore contextual and political. By controlling flows into the palace at three thresholds and by focusing on controlling activity within the rest of the palace, the Assyrian court seems to have been able to adapt to the increasing complexity and size of the empire, without the need to change the underlying architectural model.

\title{
Bibliography
}

\author{
PNA $1 / \mathrm{I}=$ Radner 1998 \\ PNA 2/I = Baker 2000 \\ PNA 2/II = Baker 2001 \\ PNA 3/II = Baker 2011
}

Ahmad, A. Y. and J. N. Postgate. Archives from the Domestic Wing of the North-West Palace at Kalhu/Nimrud. Edubba 10. London: Nabu, 2007.

Ambos, C. "Tür und Tor (auch als Rechtsgegenstand). A. Philologisch." In Reallexikon der Assyriologie und Vorderasiatischen Archäologie 14, edited by M. P. Streck, 156-159. Berlin: de Gruyter, 2014-2016.

Baker, H. D., editor. The Prosopography of the Neo-Assyrian Empire, Volume 2, Part I: $\mathrm{H}-\mathrm{K}$. Helsinki: Neo-Assyrian Text Corpus Project, 2000.

Baker, H. D., editor. The Prosopography of the Neo-Assyrian Empire, Volume 2, Part II: L-N. Helsinki: Neo-Assyrian Text Corpus Project, 2001.

Baker, H. D., editor. The Prosopography of the Neo-Assyrian Empire, Volume 3, Part II: Š-Z. Helsinki: Neo-Assyrian Text Corpus Project, 2011.

Baker, H. D. and M. Groß. "Doing the king's work: perceptions of service in the Assyrian royal correspondence." In Official Epistolography and the Language(s) of Power. Proceedings of the First International Conference of the Research Network Imperium and Officium. Comparative Studies in Ancient Bureaucracy and Officialdom, University of Vienna, 10-12 November 2010. Papyrologica Vindobonensia 8, edited by S. Procházka, L. Reinfandt and S. Tost, 73-90. Vienna: Verlag der Österreichischen Akademie der Wissenschaften, 2015.

Bang, P. F. and D. Kołodziejczyk. “'Elephant of India:' universal empire through time and across cultures." In Universal Empire. A comparative approach to imperial culture and representation in Eurasian history, edited by P. F. Bang and D. Kołodziejczyk, 1-40. Cambridge: Cambridge U. P., 2017.

Barjamovic, G. "Pride, pomp and circumstance: palace, court and household in Assyria 879-612 BCE." In Royal Courts in Dynastic States and Empires. A global perspective. Rulers and 
elites. Comparative Studies in Governance 1, edited by J. Duindam, T. Artan and M. Kunt, 27-61. Leiden: Brill, 2011.

Botta, P.-É. Monument de Ninive. Paris: Imprimerie nationale, 1849.

Cole, S. W. and P. Machinist. Letters from Priests to the Kings Esarhaddon and Assurbanipal. SAA 13. Helsinki: Neo-Assyrian Text Corpus Project, 1998.

Dalley, S. and J. N. Postgate. The Tablets from Fort Shalmaneser. CTN 3. London: British School of Archaeology in Iraq, 1984.

Dezső, T. The Assyrian Army. I. The structure of the Neo-Assyrian army as reconstructed from the Assyrian palace reliefs and cuneiform sources. 1. Infantry. Budapest: Eötvös U. P., 2012.

Dietrich, M. The Babylonian Correspondence of Sargon and Sennacherib. SAA 17. Helsinki: NeoAssyrian Text Corpus Project, 2003.

Fales, F. M. "Neo-Assyrian texts and fragments from Copenhagen." SAAB 1/1 (1987): 17-25 and Pls. II-IV.

Fales, F. M. and J. N. Postgate. Imperial Administrative Records, Part I: palace and temple administration. SAA 7. Helsinki: Neo-Assyrian Text Corpus Project, 1992.

Foster, B. J. Before the Muses. An anthology of Akkadian literature. Bethesda: CDL, 2005.

Frahm, E. "Sanherib und die Tempel von Kuyunjik." In Festschrift für Rykle Borger zu seinem 65. Geburtstag am 24. Mai 1994. Tikip santakki mala bašmu ..., edited by S. M. Maul, 107-121. Groningen: Styx, 1998.

Fuchs, A. and S. Parpola. The Correspondence of Sargon II, Part III: letters from Babylonia and the eastern provinces. SAA 15. Helsinki: Neo-Assyrian Text Corpus Project, 2001.

Groß, M. The Structure and Organisation of the Neo-Assyrian Royal Household. PhD thesis. University of Vienna, 2014.

Groß, M. "Innovation and tradition in the sphere of Neo-Assyrian officialdom." In Tradition and Innovation in the Ancient Near East. Proceedings of the 57th Rencontre Assyriologique Internationale at Rome, 4-8 July 2011, edited by A. Archi, 251-266. Winona Lake: Eisenbrauns, 2015.

Groß, M. and R. Pirngruber. "On courtiers in the Neo-Assyrian Empire: ša rēši and mazzāz pāni." AoF 41/2 (2014): 161-175.

Hunger, H. Astrological Reports to Assyrian Kings. SAA 8. Helsinki: Neo-Assyrian Text Corpus Project, 1992.

Karlsson, M. Relations of Power in Early Neo-Assyrian State Ideology. SANER 10. Berlin: de Gruyter, 2016.

Kataja, L. and R. Whiting. Grants, Decrees and Gifts of the Neo-Assyrian Period. SAA 12. Helsinki: Neo-Assyrian Text Corpus Project, 1995.

Kertai, D. "The multiplicity of royal palaces. How many palaces did an Assyrian king need?" In New Research on Late Assyrian Palaces. Conference at Heidelberg January $22^{\text {nd }}, 2011$, edited by D. Kertai and P. A. Miglus, 11-22. Heidelberg: Heidelberger Orientverlag, 2013.

Kertai, D. "From Bābānu to Bētānu, looking for spaces in late Assyrian palaces." In The Fabric of Cities. Aspects of urbanism, urban topography and society in Mesopotamia, Greece and Rome, edited by N. N. May and U. Steinert, 189-201. Leiden: Brill, 2014.

Kertai, D. The Architecture of Late Assyrian Royal Palaces. Oxford: Oxford U. P., 2015.

Kertai, D. "The iconography of the late Assyrian crown prince." In From the Four Corners of the Earth. Studies in the iconography and cultures of the ancient Near East in honour of F. A. M. Wiggermann. AOAT 441, edited by D. Kertai and 0. Nieuwenhuyse, 111-133. Münster: Ugarit, 2017. 
Kwasman, T. and S. Parpola. Legal Transactions of the Royal Court of Nineveh, Part I: TiglathPileser III through Esarhaddon. SAA 6. Helsinki: Neo-Assyrian Text Corpus Project, 1991.

Lanfranchi, G. B. and S. Parpola. The Correspondence of Sargon II, Part II: letters from the northern and northeastern Provinces. SAA 5. Helsinki: Neo-Assyrian Text Corpus Project, 1990.

Lavan, M., R. E. Payne and J. Weisweiler. "Cosmopolitan politics: the assimilation and subordination of elite cultures." In Cosmopolitanism and Empire: universal rulers, local elites, and cultural integration in the ancient Near East and Mediterranean, edited by M. Lavan,

R. E. Payne and J. Weisweiler, 1-28. Oxford: Oxford U. P., 2016.

Liverani, M. "From city-state to empire: the case of Assyria." In The Roman Empire in Context. Historical and Comparative Perspectives, edited by J. P. Arnason and K. A. Raaflaub, 251-267. New Haven: Wiley-Blackwell, 2011.

Liverani, M. "Thoughts on the Assyrian Empire and Assyrian kingship." In A Companion to Assyria, edited by E. Frahm, 534-546. New Haven: Wiley-Blackwell, 2017.

Loud, G. and C. B. Altman. Khorsabad, Part II, the Citadel and the Town. OIP 40. Chicago: University of Chicago, 1938.

Luukko, M. "The administrative roles of the 'chief scribe' and the 'palace scribe' in the Neo-Assyrian period." SAAB 16 (2007): 227-256.

Luukko, M. The Correspondence of Tiglath-pileser III and Sargon II from Calah/Nimrud. SAA 19. Helsinki: Neo-Assyrian Text Corpus Project, 2012.

Luukko, M. and G. Van Buylaere. The Political Correspondence of Esarhaddon. SAA 16. Helsinki: Neo-Assyrian Text Corpus Project, 2002.

Mallowan, M. E. L. Nimrud and its Remains. London: Collins, 1966.

Mattila, R. The King's Magnates. A study of the highest officials of the Neo-Assyrian Empire. SAAS 11. Helsinki: Neo-Assyrian Text Corpus Project, 2000.

Meuszyński, J. Die Rekonstruktion der Reliefdarstellungen und ihrer Anordnung im Nordwestpalast von Kalhu (Nimrud) (Räume: (B.C.D.E.F.G.H.L.N.P). BaF 2. Mainz: Philipp von Zabern, 1981.

Oates, J. and D. Oates. Nimrud. An Assyrian imperial city revealed. London: British School of Archaeology in Iraq, 2001.

Parpola, S. The Correspondence of Sargon II, Part I: letters from Assyria and the west. SAA 1. Helsinki: Neo-Assyrian Text Corpus Project, 1987.

Parpola, S. Letters from Assyrian and Babylonian Scholars. SAA 10. Helsinki: Neo-Assyrian Text Corpus Project, 1993.

Parpola, S. Assyrian Royal Rituals and Cultic Texts. SAA 20. Helsinki: Neo-Assyrian Text Corpus Project, 2017.

Place, V. Ninive et l'Assyrie. Paris: Imprimerie nationale, 1867.

Pongratz-Leisten, B. Religion and Ideology in Assyria. SANER 6. Berlin: de Gruyter, 2015.

Porter, B. N. Images - Power - Politics. Figurative aspects of Esarhaddon's Babylonian policy. Philadelphia: American Philosophical Society, 1993.

Porter, B. N. “Intimidation and friendly persuasion." In Eretz-Israel: archaeological, historical and geographical studies. Hayim and Miriam Tadmor volume, edited by I. Eph'al, A. Ben-Tor and P. Machinist, 180-191. Jerusalem: Israel Exploration Society, 2003.

Postgate, J. N. Taxation and Conscription in the Assyrian Empire. Studia Pohl: Series Maior 3. Rome: Biblical Institute, 1974 a.

Postgate, J. N. "Royal exercise of justice under the Assyrian Empire." In Le palais et la royauté. (Archéologie et Civilisation). XIXe Rencontre Assyriologique Internationale, Paris: 29 juin 2 juillet 1971, edited by P. Garelli, 417-426. Paris: Geuthner, 1974b. 
Radner, K., editor. The Prosopography of the Neo-Assyrian Empire, Volume 1, Part I: A. Helsinki: Neo-Assyrian Text Corpus Project, 1998.

Radner, K. "Gatekeepers and lock masters: the control of access in the Neo-Assyrian palace." In Your Praise is Sweet. A memorial volume for Jeremy Black from students, colleagues and friends, edited by H. D. Baker, E. Robson and G. Zólyomi, 269-280. London: British Institute for the Study of Iraq, 2010.

Radner, K. "The Assur-Nineveh-Arbela triangle. Central Asia in the Neo-Assyrian period." In Between the Cultures: the central Tigris region from the $3^{\text {rd }}$ to the $1^{\text {st }}$ Millennium BC, Conference at Heidelberg January $22^{\text {nd }}-24^{\text {th }}, 2009$, edited by P. A. Miglus and S. Mühl, 321-329. Heidelberg: Heidelberger Orientverlag, 2011a.

Radner, K. "Royal decision-making: kings, magnates, and scholars." In The Oxford Handbook of Cuneiform Culture, edited by K. Radner and E. Robson, 358-379. Oxford: Oxford U. P., 2011b.

Radner, K. "An imperial communication network. State correspondence of the Neo-Assyrian empire." In State Correspondence in the Ancient World. From New Kingdom Egypt to the Roman Empire, edited by K. Radner, 64-93 and 222-226. Oxford: Oxford U. P., 2014.

Reynolds, F. The Babylonian Correspondence of Esarhaddon. SAA 18. Helsinki: Neo-Assyrian Text Corpus Project, 2003.

Richardson, S. "Getting confident: the Assyrian development of elite recognition ethics." In Cosmopolitanism and Empire: universal rulers, local elites, and cultural integration in the ancient Near East and Mediterranean, edited by M. Lavan, R. E. Payne and J. Weisweiler, 29-64. Oxford: Oxford U. P., 2016.

Roth, M. T. Law Collections from Mesopotamia and Asia Minor. Writings from the Ancient World Series 6. Atlanta: Scholars, 1995.

Starr, I. Queries to the Sungod: divination and politics in Sargonid Assyria. SAA 4. Helsinki: NeoAssyrian Text Corpus Project, 1990.

Svärd, S. Women and Power in Neo-Assyrian Palaces. SAAS 23. Helsinki: Neo-Assyrian Text Corpus Project, 2015.

de Vaan, J. M. C. T. “Ich bin eine Schwertklinge des Königs.” Die Sprache des Bēl-ibni. AOAT 242. Kevelaer: Butzon and Bercker and Neukirchen-Vluyn: Neukirchener, 1995.

Winter, I. "The program of the throneroom of Ashurnasirpal II." In Essays in Near Eastern Art and Archaeology in Honor of Charles Kyrle Wilkinson, edited by P. O. Harper and H. Pittman, 1531. New York: Metropolitan Museum of Art, 1983.

Wiseman, D. J. “The Nimrud tablets, 1953.” Iraq 15/2 (1953): 135-160. 